SJ Quinney College of Law, University of Utah Utah Law Digital Commons

Wallace Stegner Center for Land, Resources, and the Environment publications

2017

NEPA, FLPMA, and Impact Reduction: An Empirical Assessment of BLM Resource Management Planning in the Mountain West

John C. Ruple

Mark Capone

Follow this and additional works at: https://dc.law.utah.edu/stegner_pubs

Part of the Environmental Law Commons, and the Natural Resources Law Commons 


\title{
NEPA, FLPMA, AND IMPACT REDUCTION: AN EMPIRICAL ASSESSMENT OF BLM RESOURCE MANAGEMENT PLANNING AND NEPA IN THE MOUNTAIN WEST
}

\author{
BY \\ JOHN RUPLE* \& MARK CAPONE**
}

This Article reviews Environmental Impact Statements (EIS) completed in conjunction with Resource Management Plan (RMP) revisions conducted by the Bureau of Land Management (BLM) in Colorado, Montana, Utah, and Wyoming between 2004 and 2014. Based on our review of sixteen EISS, we found that RMP revisions increased application of more protective surface use stipulations by statistically significant amounts without causing a statistically significant change in either the number of jobs created or the pace of oil and gas development. In fact, both the number of jobs created and wells drilled increased slightly despite strengthened environmental protections. We also found that Draft RMP EISs that are completed on an accelerated timeline come with a heightened risk that supplementation will be needed. The delays associated with preparing a Supplemental EIS far outweigh the timesaving associated with fast-tracking Draft EIS preparation and provide a strong caution against rushing the NEPA process.

\footnotetext{
* Associate Professor of Law (Research) and Wallace Stegner Center Fellow, S.J. Quinney College of Law at the University of Utah.

** Attorney Advisor, Office of the General Counsel, National Oceanic and Atmospheric Administration, United States Department of Commerce.

The authors would like to thank the 444S Foundation, the Natural Resources Defense Council, and the Partnership Project for assistance funding this research effort. This project would not have been possible without their generous support. Project funders were not, however, involved in study design; in the collection, analysis and interpretation of data; in the writing of the report; or in any other aspect of the research. The authors would also like to thank Professor Robert Keiter for his careful review of and thoughtful comments on drafts of this paper. The authors are also grateful to Seth Latimer, Senior Research Analyst at the University of Utah's College of Nursing, and Jason L. Jones, Ecologist/Herpetologist with the Nevada Department of Wildlife, for their assistance with the statistical analysis contained herein. The authors are solely responsible for the opinions, recommendations, and any errors or omissions contained herein. Furthermore, the views and opinions expressed herein do not reflect those of the National Oceanic and Atmospheric Administration.
} 


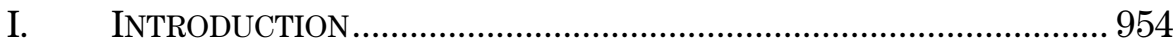

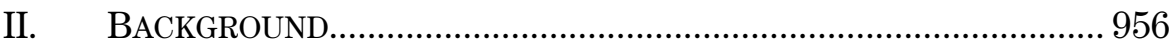

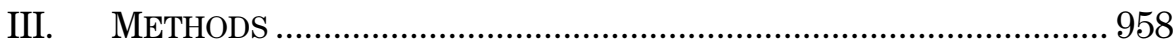

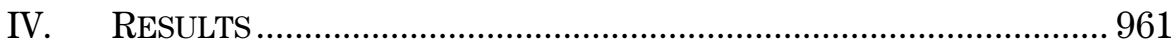

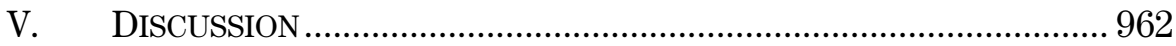

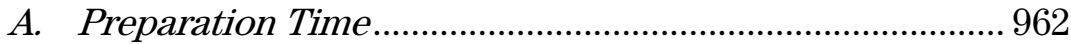

B. Environmental Impact Reduction ..................................... 964

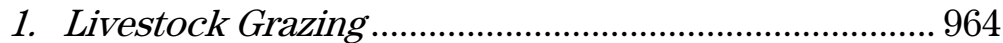

2. Areas of Critical Environmental Concern ................... 964

3. Routes Designated as Open to Vehicle Travel ............ 967

4. Terrain Open to Cross-County Motorized Travel....... 969

5. Oil and Gas Development .............................................. 970

6. Air Quality.................................................................... 972

C. Impacts on Economic Metrics ......................................... 973

D. Impact Reduction and Causation ...................................... 973

1. Subsequent Impact Reduction ...................................... 973

2. Reductions Driven by Other Environmental Laws..... 974

3. Intervening Technological Factors.............................. 975

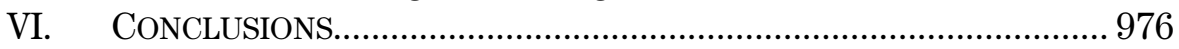

\section{INTRODUCTION}

The National Environmental Policy Act ${ }^{1}$ (NEPA) requires that, prior to making, authorizing, or funding any "major Federal action significantly affecting the quality of the human environment," the lead federal agency must prepare a detailed statement discussing the environmental impacts resulting from the proposed action, and alternative means of satisfying the purpose and need for the proposed action. ${ }^{2}$ The scope and intensity of impacts associated with the proposed action determine the level of analysis required, with the most significant projects necessitating completion of an Environmental Impact Statement (EIS). ${ }^{3}$

NEPA has proven to be a controversial statute, with supporters claiming that it enhances public involvement and leads to environmentally aware decision making. ${ }^{4}$ Detractors contend that NEPA is unduly burdensome and unnecessarily expensive, that it results in unnecessary and unreasonable project delays, and that the burden of compliance outweighs speculative environmental benefits. ${ }^{5}$ These competing claims are difficult to evaluate because NEPA is a purely procedural statute, and statutory

1 National Environmental Policy Act of 1969, 42 U.S.C. $\S \S 4321-4370(h)$ (2012).

2 Id. $\S 4332(2)(\mathrm{C})$

340 C.F.R. §§ 1501.3-.4 (2015).

4 See DANiel R. MANDElKer ET AL., NEPA LAW AND Litigation § 11:2 (2016) (summarizing the arguments of supporters and detractors of NEPA).

5 Id. 
compliance is measured with regard to the adequacy of the investigation rather than the environmental impacts resulting from the final decision. ${ }^{6}$ Indeed, "[i]f the adverse environmental effects of the proposed action are adequately identified and evaluated, the agency is not constrained by NEPA from deciding that other values outweigh the environmental costs." Furthermore, as the United States Government Accountability Office explained recently, "agency activities under NEPA are hard to separate from other environmental review tasks under federal laws, such as the Clean Water Act and the Endangered Species Act; executive orders; agency guidance; and state and local laws."

These difficulties in evaluating NEPA efficacy aside, we hypothesize that NEPA compliance is likely to result in final agency decisions that are less damaging to the environment. ${ }^{9}$ We believe that impact reduction is a byproduct of careful consideration of environmental consequences through an open and public process. If our hypothesis holds true, that finding would argue against efforts to exempt certain projects from NEPA analysis or to severely limit the scope of the analysis. ${ }^{10}$ If our hypothesis is proven wrong, that finding would highlight a need for NEPA reform.

To test this hypothesis we previously evaluated EISs for large oil and gas $(\mathrm{O} \& \mathrm{G})$ development projects in Colorado, Montana, Utah, and Wyoming to determine whether a significant reduction in environmental impacts occurred between the initial project proposal and the final agency decision, and whether reductions carried with them a commensurate economic cost, as measured in terms of job and tax revenue creation. ${ }^{11}$ We concluded that NEPA compliance does appear to lead to final decisions that have substantially less impact on the environment when compared to initially proposed projects. "While reductions may be partially attributable to factors external to NEPA..., external factors alone do not adequately explain impact reductions." ${ }^{13}$ We also found that the number of alternatives considered within an EIS affects impact reduction, with EISs considering a

6 Md.-Nat'l Capital Park \& Planning Comm'n v. U.S. Postal Serv., 487 F.2d 1029, 1040 (D.C. Cir. 1973) ("There are a number of criteria that can be used by a court to make such a determination. First, did the agency take a 'hard look' at the problem, as opposed to bald conclusions, unaided by preliminary investigation?... Second, did the agency identify the relevant areas of environmental concern?").

7 Robertson v. Methow Valley Citizens Council, 490 U.S. 332, 350 (1989).

8 U.S. Gov't ACCOUnTability OFFICE, GAO-14-370, National EnVIRONMENTAL Policy ACT: LITTLE INFORMATION EXISTS ON NEPA ANALYSES 11 (2014); Federal Water Pollution Control Act, 33 U.S.C. §§ 1251-1387 (2012); Endangered Species Act of 1973, 16 U.S.C. §§ 1531-1544 (2012).

9 Accord R.V. Bartlett, The Rationality and Logic of NEPA Revisited, in ENVIRONMENTAL POLICY AND NEPA: PAST, PRESENT, AND FUTURE 51, 55-56 (Ray Clark \& Larry Canter eds., 1997).

10 See, e.g., H.R. 1526, 113th Cong. §104(c)(1) (as passed by House, Sept. 20, 2013) (proposing to exempt certain projects in Forest Reserve Revenue Areas from the requirement under NEPA to examine alternatives to the proposed agency action).

11 John Ruple \& Mark Capone, NEPA-Substantive Effectiveness Under a Procedural Mandate: Assessment of Oil and Gas EISs in the Mountain West, 7 GEO. WASH. J. ENERGY \& ENVTL. L. 39 (2016).

12 Id. at $50-51$.

13 Id. at 51. 
broader range of alternatives more effectively reducing environmental impacts. $^{14}$

This Article reviews EISs completed in conjunction with Resource Management Plan (RMP) revisions completed by the United States Bureau of Land Management (BLM) across the same geographic area and over the same timespan as our previous work. We seek to determine whether RMPs exhibit comparable impact reductions at similarly low economic costs. We also seek to clarify how phased NEPA reviews work together to address environmental impacts, with RMP NEPA reviews first determining which lands are available for development and under what conditions development can occur, and field development NEPA reviews addressing the site-specific approval of specific development plans.

\section{BACKGROUND}

BLM currently administers 247 million acres of federal lands, more land than any other federal agency. ${ }^{15}$ BLM also administers subsurface minerals across a 700 million-acre federal estate. ${ }^{16}$ The Federal Land Policy and Management $\mathrm{Act}^{17}$ (FLPMA) requires BLM to "prepare and maintain on a continuing basis an inventory of all public lands and their resource[s]."18 Based on this inventory, BLM must "develop, maintain, and, when appropriate, revise land use plans which provide by tracts ... for the use of the public lands. ${ }^{19}$ These plans, commonly referred to as RMPs, must be developed with public involvement. ${ }^{20}$ Each RMP establishes management direction for a discrete region of public land that can cover millions of acres, and that direction can last a decade or more. ${ }^{21}$ Critical RMP decisions include, but are not limited to: which lands will be available for mineral development, which lands will be managed to emphasize resource protection, and what management stipulations are required to balance BLM's multiple use and sustained yield mandates across the federal landscape. ${ }^{22}$

Because RMPs typically cover several million acres, they may lack the resolution needed to adequately assess the resources and environmental impacts that will result from subsequent development. Many resources, even

\footnotetext{
14 Id.

15 Carol H. Vincent et Al., Cong. Research Serv., R42346, Federal Land Ownership: OVERVIEW AND DATA 8 (2014).

16 Id. at 9.

17 Federal Land Policy and Management Act of 1976, 43 U.S.C. $\S ~ 1701-1787$ (2012).

18 Id. $\S 1711(\mathrm{a})$.

19 Id. $\S 1712(\mathrm{a})$.

20 Id. $\S 1712(\mathrm{c})(9)$.

21 See, e.g., Boise Field Office, U.S. Bureau of Land Mgmt., Owyhee Resource MANAGEMENT PLAN AND RECORD OF DECISION 1 (1999) (in place for over a decade and covering over one-million acres of public land).

2243 U.S.C. $\S 1701(a)(7)$ (2012) (requiring BLM to manage on the basis of multiple use and sustained yield); e.g., Pinedale Field Office, U.S. Bureau of Land Mgmt., Pinedale MANAGEMENT SituATiON ANALYSIS 2-1 to -38 (2003).
} 
if mapped adequately, are simply too small to show up at the multimillion acres planning scale. ${ }^{23}$ Furthermore, determining which areas should be available to lease for future O\&G development does not guarantee that those lands will be of interest to O\&G operators. Even if interest exists, the timing and scale of development are unknown at the planning phase, as are project specific details like road, well pad, and utility locations. Accordingly, development level decisions are typically deferred for consideration in a subsequent EIS that "tiers" to the earlier RMP decision. ${ }^{24}$

Under NEPA, RMP revisions are invariably considered "major Federal actions significantly affecting the quality of the human environment., ${ }^{25}$ As such, RMP development and revision requires the completion of an EIS. ${ }^{26}$ EISs are part of an iterative analytical and decision-making process that begins with publication of a Notice of Intent (NOI) to prepare an EIS. ${ }^{27}$ The NOI kicks off a public scoping period in which the public is invited to submit comments about the proposal, the environmental issues the proposal raises, and potential alternative means of achieving the purpose and need driving the proposed action. ${ }^{28}$ Those comments help the lead federal agency identify issues and develop alternatives to the proposed action. The reasonably foreseeable direct, indirect, and cumulative impacts anticipated to result from implementation of each alternative are then analyzed and disclosed in a Draft EIS (DEIS). ${ }^{29}$ The DEIS is made available for public review and comment. ${ }^{30}$ After receiving and considering public input, the lead federal agency releases a Final EIS (FEIS) that reflects public input on the agency's methods and analysis. ${ }^{31}$ Following another public review period, the lead federal agency then issues a Record of Decision (ROD) stating the agency's decision and initiating a protest or appeals period. ${ }^{32}$

The result is an iterative process whereby additional information can be acquired or considered, and actions and alternatives can be revised to reflect new information and public input. Indeed, the deciding official need not select one of the alternatives evaluated in the EIS provided that the selected alternative, which may combine elements of other alternatives, is within the

23 Land-Use Issues Associated with Onshore Oil and Gas Leasing and Development: Joint Oversite Hearing Before the H. Subcomm. On Nat'l Parks, Forests \& Pub. Lands and the H. Subcomm. On Energy \& Mineral Res. of the H. Comm. On Nat'l Res., 110th Cong. 46 (2007) (statement of John Emmerich, Deputy Director, Wyoming Fish \& Game Department) ("The level of analysis, disclosure and recommended mitigation that is appropriate for sensitive wildlife corridors and crucial habitat is not provided in programmatic land use plans such as RMPs ... [it] can only be achieved through the more in depth analysis provided by an EA or in most cases an EIS ....").

2440 C.F.R. $\$ 1502.20$ (2015).

25 NEPA, 42 U.S.C. $\$ 4332(2)(C)(2012)$.

2643 C.F.R. $\S 1601.0-6(2015)$.

27 Id. $\S 1501.7$.

28 Id. $\S 1501.7(\mathrm{a})$.

29 Id. $\S \S 1502.9(\mathrm{~b}), 1508.8$.

30 Id. $\S 1503.1(\mathrm{a})(4)$.

31 Id. $\S 1502.9(\mathrm{~b})$.

32 Id. $\S 1505.2$. 
range of alternatives considered. ${ }^{33}$ Iterative change occurs both at the planning (e.g., RMP) and implementation (e.g., O\&G development) level.

The iterative nature of the FLPMA/NEPA process frequently results in changes to the proposed action, and these changes can result in significant reductions in environmental impacts. As we noted in an earlier publication, O\&G development projects that are analyzed in an EIS typically see a reduction in impacts over the course of the NEPA process. ${ }^{34}$ Some of the most significant impact reductions identified involved reductions in surface disturbing activity. ${ }^{35}$ Air pollutant emissions also commonly experienced reductions, particularly with respect to precursors of ground-level ozone. ${ }^{36}$

This Article reviews the iterative changes that occur during the RMP revision process. We compare the environmental impacts associated with continuation of current management activities as reflected in the "No Action Alternative, ${ }^{37}$ the "Proposed Alternative" in the DEIS, and BLM's "Preferred Alternative" in the FEIS to the approved plan documented in the ROD. We also compare, where possible, the amount of impact reduction that occurs during the RMP planning phase to reductions occurring during the O\&G implementation phase.

\section{METHODS}

We focus on EISs for RMPs because RMPs include the predicate decisions of which BLM-managed lands will be available for O\&G development, and, for those lands, what management stipulations will apply. As such, RMPs represent the first major discretionary agency decision that can significantly reduce project-related environmental impacts. ${ }^{38}$ In order to allow for longitudinal consideration of RMPs, EISs, and O\&G EISs, we limited our analysis to the same four-state region considered in our earlier

33 See, e.g., Defs. of Wildlife v. N.C. Dep't of Transp., 762 F.3d 374, 397 (4th Cir. 2014) (affirming NEPA compliance where the defendants authorized construction of a project that mixed and matched components considered in the EIS).

34 Ruple \& Capone, supra note 11, at 44.

35 Id.

36 Id. (noting statistically significant changes in nitrogen oxides $\left(\mathrm{NO}_{\mathrm{x}}\right)$ emissions).

37 The "no action alternative" does not contemplate the absence of federal action, but rather, "may be thought of in terms of continuing with the present course of action until that action is changed." Forty Most Asked Questions Concerning CEQ's National Environmental Policy Regulations, 46 Fed. Reg. 18,026, 18,031 (Apr. 25, 1986).

38 Our analysis captures management decisions at a moment in time. Decisions, like those contained in programmatic RMP amendments addressing greater sage grouse management, master leasing plans, or RMP amendments can change these decisions or add additional management constraints not considered in our analysis. See, e.g., U.S. Bureau of Land Mgmt., Sage-Grouse and Sagebrush Conservation, http://www.blm.gov/wo/st/en/prog/more/sage grouse.html (last visited Nov. 19, 2016); CANYON COUNTRY DIST. OFFICE, U.S. BUREAU OF LAND Mgmt., Moab Master Leasing Plan and Draft Resource Management Plan

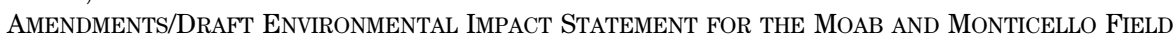
OFFICES (2015). 
assessment of O\&G NEPA: Colorado, Montana, Utah, and Wyoming. ${ }^{39}$ Similarly, we limited our analysis to RMP EISs completed during the same period, which began in January 2004 and ended in October $20144^{40} \mathrm{We}$ identified sixteen EISs satisfying our selection criteria using the EIS Database maintained by the United States Environmental Protection Agency (EPA). ${ }^{41}$ RMP EISs are listed in Table 1.

Table 1: RMPs Analyzed

\begin{tabular}{|lc|}
\hline Montana & Colorado \\
Butte Field Office & Little Snake Field Office \\
Dillon Field Office & Roan Plateau Field Office \\
Upper Mo. Breaks Nat'l Monument & Utah \\
Wyoming & Kanab Field Office \\
Casper Field Office & Moab Field Office \\
Kemmerer Field Office & Monticello Field Office \\
Lander Field Office & Price Field Office \\
Pinedale Field Office & Richfield Field Office \\
Rawlins Field Office & Vernal Field Office \\
\hline
\end{tabular}

We obtained and reviewed every DEIS, FEIS, Supplemental EIS (if any), and ROD for each RMP revision meeting our selection criteria. Impact metrics associated with the No Action Alternative (continuation of ongoing management), the proposed action in the DEIS, Preferred Alternative in the FEIS, and agency decision contained in the ROD were recorded consistent with our earlier work. ${ }^{42}$ We also recorded document release dates and the number of alternatives considered in each document. A complete set of impact metrics identified and entered is listed in Table 2.

For RMP EISs, our design allowed us to compare the potential environmental impacts of a plan at four stages: 1) the existing conditions, reflected in the No Action Alternative; 2) the DEIS proposed action; 3) the FEIS Preferred Alternative; and 4) the ROD approved plan. Determining whether NEPA reduces environmental impacts required only the comparison of the DEIS No Action Alternative to the plan approved in the ROD. We used single-tailed paired $t$-tests to compare environmental impacts

39 BLM manages 57.4 million acres of land surface across our four-state analysis area and 143.6 million acres of subsurface mineral across the four-state analysis area. U.S. BUREAU OF Land Mgmt., Public Land Statistics 2013, at 7 (2014) [hereinafter Public Land Statistics 2013].

40 As initially envisioned, this research effort included EISs across a broader geographic area and involving a wider range of proposed activities. While this approach resulted in a larger sample size, differences in issues of concern and associated impact indicators included in each EIS made it impossible to meaningfully compare across diverse project types and regions. Focusing on similar projects, within a common region and over the same period of time, ensures comparability.

41 U.S. Envtl. Prot. Agency, Environmental Impact Statement (EIS) Database, https://cdxnodengn.epa.gov/cdx-enepa-II/public/action/eis/search/search\#results (last visited Nov. 19, 2016).

42 See Ruple \& Capone, supra note 11, at 40-43. 
from the DEIS and the ROD. However, a comparison of data at various points during the NEPA process allows us to determine where most of the change occurs.

Table 2: RMP Project Metrics

- Number Animal Unit Months (AUMs) of livestock grazing authorized

- Acres of Areas of Critical Environmental Concern (ACECs) designated

- Miles of routes designated as open to motorized use

- Acres of terrain open to cross-country motorized travel

- $\quad$ Acres of land open to mineral development under:

o Standard lease terms and conditions

o Timing limits or conditional surface use (minor constraints)

o No surface occupancy (major constraints)

o Closed to leasing

- Number of O\&G wells drilled

- O\&G related jobs created

- Air emissions:

o Particulate Matter $\left(\mathrm{PM}_{10}\right)$

o Fine Particulate Matter $\left(\mathrm{PM}_{2.5}\right)$

o Nitrogen Oxides $\left(\mathrm{NO}_{\mathrm{x}}\right)$

o Sulfur Dioxide $\left(\mathrm{SO}_{2}\right)$

The single-tailed test reflects our hypothesis that NEPA results in reduced environmental impacts. ${ }^{43}$ The paired $t$-test is appropriate because we are comparing data from the same EISs but at different stages of the process. ${ }^{44}$ Given the exploratory nature of this study, prior to conducting the analysis, we determined that $p$-values less than .05 would be considered significant, and that $p$-values between .05 and .10 are considered to be trending towards significance. ${ }^{45}$ Given our small sample size and the

43 See Dawn Hawkins, Biomeasurement: A Student's Guide To Biological statistics 80 (3d ed. 2014) (describing when a single-tailed test is appropriate).

44 See id. at 143. As shown in Table 2, we conducted statistical analysis on fourteen different impact metrics. We acknowledge that as the number of statistical comparisons in a study increases, so too does the probability of that study finding a false positive result-finding a statistically significant difference in a particular impact metric when in fact that difference does not exist. This is known as a "multiple comparisons problem." Id. at 164. There is considerable debate within the statistical literature as to the proper approach to dealing with a multiple comparison problem, with some scholars recommending additional statistical methods to "correct" for multiple comparisons, and others arguing against the use of corrective measures. See Kenneth J. Rothman, No Adjustments Are Needed for Multiple Comparisons, 1 EPIDEMIOLOGY 43 passim (1990). Corrective measures generally reduce the risk of false positives by adjusting the $p$-value threshold for significance. Accordingly, these corrective measures reduce the risk of false positives at the cost of increasing the risk of false negatives-not detecting a significant result when one in fact exists. Id. In light of this tradeoff and given the exploratory nature of our study, we did not apply corrective measures to our analysis.

45 NATAlie L. SpRoull, HaNdBoOK OF RESEARCh Methods 61 (2d. ed. 2002) ("An alpha of .10 is common for exploratory research."); see also ALFRED P. ROVAI ET AL., SOCIAL SCIENCE Research Design and Statistics: A Practitioner's Guide to Research Methods and IBM 
exploratory nature of this effort, our results should be considered to be preliminary in nature. Additional research is warranted to determine whether the relationships identified below hold across other indicators and with a larger sample size.

IV. RESULTS

Table 3.

\begin{tabular}{|c|c|c|c|c|c|}
\hline Element & $\begin{array}{l}\text { Initial Value } \\
\text { Final Value }\end{array}$ & $\begin{array}{l}\text { Change Existing } \\
\text { Conditions } \\
\text { to DEIS }\end{array}$ & $\begin{array}{l}\text { Change } \\
\text { DEIS } \\
\text { to FEIS }\end{array}$ & $\begin{array}{l}\text { Change } \\
\text { FEIS } \\
\text { to ROD }\end{array}$ & $\begin{array}{l}\text { Total } \\
\text { Change } \\
(p \text {-value })\end{array}$ \\
\hline \multicolumn{6}{|l|}{ Land Management } \\
\hline AUMs & $\begin{array}{l}114,614 \\
109,460\end{array}$ & $-5,145.4$ & -8.2 & -0.1 & $\begin{array}{l}-5,153.8 \\
(p=.093)\end{array}$ \\
\hline ACEC (acres) & $\begin{array}{l}73,292.4 \\
60,269.3\end{array}$ & $1,045.4$ & $-13,956$ & -112.7 & $\begin{array}{l}-13,023 \\
(p=.33)\end{array}$ \\
\hline $\begin{array}{l}\text { Routes Designated } \\
\text { as Open (miles) }\end{array}$ & $\begin{array}{l}2,050.7 \\
1,858.4 \\
\end{array}$ & -263.3 & -35.6 & 106.7 & $\begin{array}{c}-192.2 \\
(p=.092)\end{array}$ \\
\hline $\begin{array}{l}\text { Terrain Open to } \\
\text { Cross-County } \\
\text { Motorized Travel } \\
\text { (acres) }\end{array}$ & $\begin{array}{l}616,202 \\
205,709\end{array}$ & $-408,564$ & $-1,928.3$ & -0.7 & $\begin{array}{c}-410,493 \\
(p=.0026)\end{array}$ \\
\hline \multicolumn{6}{|c|}{ Oil and Gas Development } \\
\hline $\begin{array}{l}\text { Open to Mineral } \\
\text { Development with } \\
\text { Standard Lease } \\
\text { Terms and } \\
\text { Conditions (acres) }\end{array}$ & $\begin{array}{l}567,856 \\
421,125\end{array}$ & $-93,409$ & $-73,075$ & 19,753 & $\begin{array}{l}-146,731 \\
(p=.021)\end{array}$ \\
\hline $\begin{array}{l}\text { Open to Mineral } \\
\text { Development with } \\
\text { Minor Constraints } \\
\text { (acres) }\end{array}$ & $\begin{array}{c}937,434 \\
1,017,535\end{array}$ & $44,655.7$ & $50,543.7$ & $-15,099$ & $\begin{array}{c}80,100.4 \\
(p=.78)\end{array}$ \\
\hline $\begin{array}{l}\text { Open to Mineral } \\
\text { Development with } \\
\text { Major Constraints } \\
\text { (acres) }\end{array}$ & $\begin{array}{l}209,533 \\
359,017\end{array}$ & $100,924^{*}$ & $47,295.5$ & 1,265 & $\begin{array}{l}149,484 \\
(p=.019)\end{array}$ \\
\hline $\begin{array}{l}\text { Not Open to } \\
\text { Mineral } \\
\text { Development } \\
\text { (acres) }\end{array}$ & $\begin{array}{l}171,845 \\
245,063\end{array}$ & $46,266.7$ & $25,402.4$ & $1,549.3$ & $\begin{array}{c}73,218.4 \\
(p=.0044)\end{array}$ \\
\hline Wells Drilled & $\begin{array}{l}2,229.9 \\
2,285.1\end{array}$ & 14.8 & 40.5 & -0.1 & $\begin{array}{c}55.2 \\
(p=.85)\end{array}$ \\
\hline
\end{tabular}

SPSS ANAlysis 179 (2014) (same); Steven R. BRown \& LAWRENCE E. MELAMED, Experimental DESIGN AND ANALYSIS 28 (1990) (same). 


\begin{tabular}{|c|c|c|c|c|c|}
\hline Element & $\begin{array}{l}\text { Initial Value } \\
\text { Final Value }\end{array}$ & $\begin{array}{l}\text { Change Existing } \\
\text { Conditions } \\
\text { to DEIS }\end{array}$ & $\begin{array}{l}\text { Change } \\
\text { DEIS } \\
\text { to FEIS }\end{array}$ & $\begin{array}{l}\text { Change } \\
\text { FEIS } \\
\text { to ROD }\end{array}$ & $\begin{array}{l}\text { Total } \\
\text { Change } \\
\text { (p-value) }\end{array}$ \\
\hline Jobs Created & $\begin{array}{l}3,935.9 \\
4,236.3 \\
\end{array}$ & 285.1 & 15.3 & 0 & $\begin{array}{c}300.3 \\
(p=.82)\end{array}$ \\
\hline \multicolumn{6}{|l|}{ Air Quality } \\
\hline $\mathrm{PM}_{10}$ (tons/year) & $\begin{array}{l}1,669.6 \\
1,748.8 \\
\end{array}$ & 79.2 & 0 & 0 & $\begin{array}{c}79.2 \\
(p=.91) \\
\end{array}$ \\
\hline $\mathrm{PM}_{2.5}$ (tons/year) & $\begin{array}{l}1,087.1 \\
1,074.2 \\
\end{array}$ & -12.9 & 0 & 0 & $\begin{array}{c}-12.9 \\
(p=.34) \\
\end{array}$ \\
\hline NOx (tons/year) & $\begin{array}{l}6,088.6 \\
5,992.9 \\
\end{array}$ & -95.7 & 0 & 0 & $\begin{array}{c}-95.7 \\
(p=.066)\end{array}$ \\
\hline SOx (tons/year) & $\begin{array}{l}631.6 \\
630.1 \\
\end{array}$ & -1.5 & 0 & 0 & $\begin{array}{c}-1.5 \\
(p=.15)\end{array}$ \\
\hline
\end{tabular}

\section{DISCUSSION}

\section{A. Preparation Time}

RMPs and their associated EISs take longer to complete than EISs for O\&G development projects. On average, it takes $39.2 \%$ more time to go from NOI to ROD for an RMP EIS (an average of 2,252.4 days, with a range from 1,625 to 2,665 days) than for an O\&G EIS (an average of 1,617.9 days, with a range from 1,057 to 2,556 days). ${ }^{46}$ Our RMP and O\&G EIS results are consistent with deWitt and deWitt's work, where they found that BLM RMP and non-RMP EISs required, on average, 2,037 and 1,421 days to complete, respectively. ${ }^{47}$

We found that all phases of the RMP EIS process took longer to complete than their O\&G EIS counterparts. RMPs took, on average, 1,336.8 days to proceed from NOI to DEIS (with a range of 778 to 2,160 days) as compared to O\&G EISs that took on average, 990.5 days (with a range of 476 to 1,694 days). RMPs took an average of 661.9 days to proceed from DEIS to FEIS (with a range of 274 to 1,492 days), whereas O\&G EISs required on average, only 562.5 days (with a range of 182 to 910 days). RMPs took an average of 253.8 days for BLM to proceed from FEIS to ROD (with a range of 91 to 643 days), as compared to 71.5 days (with a range of 0 to 243 days) for O\&G EISs. These differences are not surprising, as an RMP EIS combines both FLPMA planning and subsequent impact analysis, reflecting both greater geographic scope and breadth of issues. In contrast, O\&G EISs are conducted in response to plans developed by the operator and, when tiered to a recent RMP EIS, O\&G EISs can reduce preparation time by incorporating that prior analysis. ${ }^{48}$ Furthermore, RMPs expedite later O\&G

46 Ruple \& Capone, supra note 11, at 43.

47 Piet deWitt \& Carole A. deWitt, Preparation Times for Final Environmental Impact Statements Made Available from 2007 through 2010, 15 ENVTL. PRAC. 123, 128 (2013).

48 See 40 C.F.R. $\$ 1502.20$ (2015) (CEQ's NEPA tiering rule). 
EISs by restricting or precluding development in areas with the greatest potential for resource conflicts, minimizing or eliminating the analysis of these issues at the project implementation phase.

RMPs that required supplementation to cure a defect in their analysis or disclosure $(n=3)$ moved from the NOI to DEIS in an average of 977 days (with a range of 778 to 1,186 days), as compared to an average of 1,419.8 days (with a range of 935 to 2,160 days) for RMPs that did not require supplementation ( $n=13)$. RMPs that required supplementation reached the DEIS stage in average of 442.8 days or $31 \%$ faster than those that did not require supplementation. This difference was significant $(p=0.03)$. However, the overall time for completion, as measured from NOI to ROD, was an average of 2,547.7 days (with a range of 2,508 to 2,585 days) for RMPs that required supplementation, as compared to an average 2,184.3 days (with a range of 1,625 to 2,665 days) for those that did not require supplementation. Supplementation, therefore, resulted in a delay averaging 363.4 days. This represents a $17 \%$ increase in the time necessary to complete the NEPA review. This difference was statistically significant $(p=0.005)$.

While our sample size is too small to draw definitive conclusions, it appears that accelerated DEIS preparation may increase the likelihood that significant issues will be overlooked in the DEIS. Indeed, of the three DEISs prepared most rapidly, two required supplementation. The relationship between preparation time and supplementation may indicate that criticisms raised during the public comment period, which drive supplementation, ${ }^{49}$ are well founded, especially when applied to a hastily prepared DEIS.

This relationship between rapid DEIS preparation and required supplementation may provide agencies with an important caution against rushing DEIS preparation, as RMP revisions requiring EISs supplementation took, on average, almost one full year longer (363.4 days) than their counterparts, which have not been supplemented, to reach a ROD. DeWitt and deWitt found that projects requiring supplementation take an average of 835 days longer to complete than those that do not require supplementation. ${ }^{50}$ Based on the projects we reviewed, BLM does a better than average job of completing supplementations in a timely manner, at least with respect to RMPs. However, careful EIS preparation that minimizes the likelihood of supplementation, appears to be a more effective way of expediting the NEPA process.

49 See, e.g., Letter from Henri Bisson, Acting State Dir., Utah State Office, U.S. Bureau of

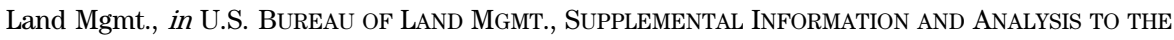
Price Field Office Draft Resource Management Plan/Environmental Impact Statement for Areas of Critical Environmental Concern (2006) ("In July 2004, the BLM Price Field Office released the DRMP/DEIS for public review and comment and inadvertently omitted consideration of four potential Areas of Critical Environmental Concern (ACECs)... [I]nformation was provided during the public comment period for the DRMP/DEIS which further substantiates the need to consider these potential ACECs. Supplemental information and analysis has therefore been prepared to provide a description of these four potential ACECs ....").

50 Piet deWitt \& Carole A. deWitt, How Long Does It Take to Prepare an Environmental Impact Statement?, 10 ENVTL. PRAC. 164, 170 (2008). 


\section{B. Environmental Impact Reduction}

\section{Livestock Grazing}

BLM manages livestock grazing on 155 million acres nationwide, overseeing 18,000 permits and leases held by ranchers who graze their livestock at least part of the year on the more than 21,000 allotments under BLM management. ${ }^{51}$ Grazing is measured in animal unit months (AUMs), which represent the amount of forage needed to sustain one cow and her calf, one horse, or five sheep or goats for a month. ${ }^{52}$ As part of the RMP revision process, BLM identifies lands as available or not available for livestock grazing based on consideration of range conditions and other land uses. ${ }^{53}$ As part of the RMP revision process, BLM also determines how many AUMs to allocate to livestock on each allotment. ${ }^{54}$

We found that the number of AUMs authorized declined during RMP revisions by an average of 5,154 , or $4 \%$, with the vast majority of the change occurring between the existing conditions and the DEIS. This reduction is trending towards significance $(p<0.10)$.

The AUM reduction, however, reflects only the change in the amount of forage allocated for livestock grazing rather than the amount of grazing that is actually authorized and occurring. Once allocated, BLM must still assess range conditions, which can be impacted by factors such as drought, wildfire, and wildlife grazing. ${ }^{55}$ Where range conditions are unable to support the full amount of allocated livestock grazing, BLM may suspend grazing authorizations. ${ }^{56}$ For example, as of October 18,2013 , 14.5\% of BLM grazing permits and leases within the four-state area were held in suspension. ${ }^{57}$ Reductions in actual livestock grazing levels may therefore exceed those reported here as management decisions subsequent to RMP preparation may incorporate additional grazing reductions resulting in further impact reductions.

\section{Areas of Critical Environmental Concern}

FLPMA directs BLM to give priority to the designation and protection of areas of critical environmental concern (ACEC) ${ }^{58}$ FLPMA defines ACECs as

\footnotetext{
51 U.S. Bureau of Land Mgmt., Fact Sheet on the BLM's Management of Livestock Grazing, http://www.blm.gov/wo/st/en/prog/grazing.html (last visited Nov. 19, 2016).

52 Id.; 43 C.F.R. $\$ 4100.0-5$ (2015)

53 U.S. Bureau Of Land Mgmt., H-1601-1, Land Use Planning Handbook app. C at 14 (2005) [hereinafter LAND Use PLANNING HANDBOOK].

54 Id.

55 U.S. Bureau of Land Mgmt., Manual $\S 4100.06$.B (2009). See generally id. $\S 4710.42$ (2010) (including grazing utilization as a consideration when establishing the Appropriate Management Level of wild horses and burros).

56 Grazing Administration-Exclusive of Alaska, 71 Fed. Reg. 39,402, 39,427 (July 12, 2006).

57 Public Land Statistics 2013, supra note 39, at 89-90 tbls. 3-9a, 3-9b (deriving from suspension data).

58 FLPMA, 43 U.S.C. $§ 1711$ (a) (2012).
} 
"areas within the public lands where special management attention is required ... to protect... important historic, cultural, or scenic values, fish and wildlife resources or other natural systems, or to protect life and safety from natural hazards. ${ }^{59}$ Unlike other conservation designations that include uniform protective requirements, ACEC designation requires development of site-specific management requirements that are tailored to each ACEC's unique resources. ${ }^{60}$ Designation, therefore, does not uniformly change land management, ${ }^{61}$ and "protection of ACECs has also been quite inconsistent throughout the states."

In the ten-year period from 2003 to 2013, the total acreage of ACECs designated nationally rose from $12,884,998$ to $21,432,759 .{ }^{63}$ During this period, the ACEC acreage for the four states within our study decreased from $2,797,104$ to $2,218,712 .{ }^{64}$ Our analysis shows an $18 \%$ reduction in the average acreage of ACECs designated during the RMP revision process. This reduction was not statistically significant, likely because of the high level of inter-RMP variability.

In our study, Colorado, Montana, and Wyoming RMP revisions increased the acreage of ACEC designation by an average of 6,017 acres (with a range between $-9,000$ to 21,034 acres), 66,074.5 acres (with a range between 58,965 to 73,184 acres), and 17,203.7 acres (with a range between 17,420 to 124,216 acres) respectively. In contrast, Utah RMPs resulted in an average ACEC decrease of 75,963 acres (with a range between $-418,585$ to 61,429 acres). We suspect the observed reduction in ACEC acreage is partially explained by the State of Utah's strong policy against ACEC designation. Utah opposes ACEC designation unless, among other factors, the ACEC area:

is limited in geographic size and that the proposed management prescriptions are limited in scope to the minimum necessary to specifically protect and

59 Id. $\S 1702(\mathrm{a})$.

60 E.g., Moab Field Office, U.S. Bureau of Land Mgmt., Moab Field Office Record of Decision and APPRoved Resource Management Plan 34 (2008) [hereinafter Moab ROD] ("[M]anagement actions are tailored for the Ten Mile Wash ACEC to protect the relevant and important values of natural systems, wildlife, cultural resources, and natural hazards. Management actions include a no surface occupancy stipulation for oil and gas leasing and other surface disturbing activities, restricting grazing, no competitive events, no woodcutting, restrictions on camping and the establishment of a speed limit. These special management actions are necessary to protect the relevant and important values. The Establishment of Ten Mile as an ACEC gives priority to the management of the resource values identified in this area.").

6143 U.S.C. $\$ 1711$ (a) (2012).

62 Kelly Nolen, Residents at Risk: Wildlife and the Bureau of Land Management's Planning Process, 26 ENVTL. L. 771, 815 (1996).

63 Public LAND STATISTICS 2013, supra note 39, at 240 tbl.5-15 (BLM includes Research Natural Areas in its presentation of ACEC acreage in the 2013 report); U.S. BUREAU OF LAND Mgmt., Public Land Statistics 2003, at 255 tbl.5-15 (2004) [hereinafter Public Land STATISTICS 2003] (BLM does not specify if Research Natural Area acreage is included in the 2003 report). In 2003, there were 323,350 acres of Research National Areas. Id. at 256 tbl.5-16.

64 Public Land Statistics 2013, supra note 39, at 240 tbl.5-15; PUBLIC LAND Statistics 2003 , supra note 63 , at 255 tbl.5-15. 
prevent irreparable damage to the relevant and important values identified, or limited in geographic size and management prescriptions to the minimum required to specifically protect human life or safety from natural hazards. ${ }^{65}$

Furthermore, Utah has adopted a policy that ACEC designation should not be "applied redundantly over existing protections provided by other state and federal laws for federal lands or resources on federal lands."

While these state policies are not binding on federal agencies, and states lack jurisdiction to dictate how BLM manages federal public lands, ${ }^{67}$ FLPMA does require that "[l]and use plans ... shall be consistent with State and local plans to the maximum extent [the Secretary of the Interior] finds consistent with Federal law and the purposes of this Act." ${ }^{168}$ The State of Utah has cited state policy and FLPMA consistency requirements when commenting on RMP revisions, and BLM may have reduced ACEC acreage in response to these comments. ${ }^{69}$ As six of the RMP revisions we evaluated involve BLM-managed lands within Utah, this policy could have an outsized effect on our analysis.

A reduction in ACEC acreage, however, does not necessarily equate to a reduction in resource protection. BLM can often achieve equal or greater protections by withdrawing areas from availability for mineral development, closing areas to off-road vehicle use, limiting grazing or timber harvesting, or adopting other protective resource management strategies that do not require ACEC designation. Changes in the acreage of ACEC designation are therefore, when compared to other quantifiable resource management stipulations, a less powerful indicator of overall changes in resource protection.

For example, designated ACECs in Utah's Price RMP declined by 52,105 acres between the outset of the RMP revision process and the ROD. ${ }^{70}$ While this appears to indicate a stark reduction in resource protection, the total amount of land subject to either no surface occupancy restrictions or

65 UTAH CODE ANN. § 63J-4-401(8)(c)(ii) (West 2015).

66 Id. § 63J-4-401(8)(c)(vii).

67 U.S. ConsT. art. VI, $\$ 2$; see, e.g., Ventura County v. Gulf Oil Corp., 601 F.2d 1080, 1083 (9th Cir. 1979), aff'd mem., 445 U.S. 947 (1980) (declaring an ordinance asserting local control over federal public lands unconstitutional).

68 FLPMA, 43 U.S.C. $§ 1712(c)(9)(2012)$.

69 Moab Field Office, U.S. Bureau of Land Mgmt., The Moab Field Office Proposed RESOURCe MANagement Plan AND Final EnVIRONMENTAL IMPACt STATEMENT 5-59 tbl.5.9.a (2008) (comment of the State of Utah) ("The state is opposed to the establishment of ACECs overlapping Wilderness Study Areas (WSAs).”); see also UTAH CODE ANN. § 63J-8-104(1)(I) (setting forth Utah's broad opposition to the designation of ACECs as such designations "are generally not compatible with the state's plan and policy for managing the subject lands," except in "special cases").

70 Compare Price Field Office, U.S. Bureau of Land Mgmt., Price Field Office Record of Decision And Approved Resource Management Plan 22 (2008) [hereinafter Price Field OfFICE ROD] (designating 13 ACECs totaling 208,555 acres), with 1 PRICE FIELD OFFICE, U.S. Bureau of Land Mgmt., The Price Field Office Proposed Resource Management Plan and Final Environmental Impact Statement 3-86 to -87 tbl.3-36 (2008) [hereinafter PRice Field OFFICE DRAFT RMP] (listing 13 ACECs totaling 266,660 acres). 
closure to leasing increased by 217,000 acres during the same period. ${ }^{71}$ The increases in no surface occupancy and closure to leasing stipulations exceeded the decreases in ACEC areas by 164,895 acres.

Similarly, while ACEC designation in the Monticello RMP fell from 492,077 acres to just 73,492 acres, ${ }^{72}$ the amount of acreage open to crosscountry off-highway vehicle travel decreased by 611,310 acres, and 88,871 acres of land were protected as lands with "Wilderness Characteristics" in order to protect those resources. ${ }^{73}$ Moreover, the Monticello ROD specifically notes that portions of seven existing ACECs that were eliminated or reduced in size during the ACEC revision process overlapped with Wilderness Study Areas that are subject to stringent statutory protections, such that changed designation does not reduce resource protection. $^{74}$

At least within Utah, it therefore appears that ACEC designation is not an accurate indicator of resource protection, as reductions in designation do not appear to equate to reduced resource protection. This flexibility, and BLM's ability to fashion a management plan that responds to state policy without reducing resource protection, cuts against critiques of NEPA as inflexible. It also appears that FLPMA's requirements that BLM consult with states and create RMPs that are consistent "with State and local plans" can drive changes that reflect state and local government concerns. ${ }^{75}$

\section{Routes Designated as Open to Vehicle Travel}

BLM manages vehicle traffic in two different ways. With respect to roads, routes, and trails on BLM-managed lands, BLM determines which of these will be open to vehicle use. ${ }^{76}$ Additionally, and as discussed in the next section, BLM determines which lands will be open to cross-country offhighway vehicle travel. ${ }^{77}$

During the RMP revision process, BLM reduced the miles of roads or routes designated as open to vehicle travel by an average of 192.2 miles, or $9 \%$. This reduction was trending towards statistical significance $(p<0.10)$. A clear difference exists between the approach to route designation adopted

71 Compare PRICE FIELD OFFICE ROD, supra note 70, at 22 (designating 851,000 acres subject to such restrictions), with 1 PRICE FiELd OfFICE, U.S. BuREAU OF LAND MGMT., DRAFT Resource Management Plan and Draft Environmental Impact Statement, at ES-8 (2004) (showing 349,000 acres subject to such restrictions under the old RMP).

72 Monticello Field Office, U.S. Bureau of Land Mgmt., Monticello Field Office Proposed Resource Management Plan and Final Environmental Impact Statement, at ES-6 (2008) [hereinafter MONTICELLO RMP]. The Monticello ROD refers to these areas as "BLM natural areas." Monticello Field OfFice, U.S. BuREAU of LAND MGMT., RECORD OF DECISION AND ApProved Resource Management Plan 28 (2008) [hereinafter Monticello ROD] ("In future references, lands managed in the Approved RMP as non-WSA lands with wilderness characteristics will be referred to as BLM natural areas.").

73 Id. at ES-5 tbl.ES-1, ES-6 tbl.ES-5.

74 MONTICELlo ROD, supra note 72, at 31-34.

75 FLPMA, 43 U.S.C. $\$ 1712(c)(9)(2012)$.

7643 C.F.R. $\$ 420.2$ (2015).

77 Id. 
by field offices in different states. Field offices in Colorado and Montana all had road designation reductions of greater than $31 \%$. All Utah field offices reduced road or route designation by substantially less, if they reduced designations at all: two field offices did not change route designations during the RMP revision process, three field offices reduced designated routes by 6 to $21 \%$, and one field office increased the number of routes designated as open to vehicle travel by $29 \%$.

We suspect that ongoing litigation explains interstate differences in route designation reduction. Utah is currently litigating title to approximately 14,500 purported rights of way across federal public lands. ${ }^{78}$ While the state filed its lawsuits after the 2008 revision of six RMPs, BLM was acutely aware of the likelihood of litigation during the revision process leading up to the 2008 revision of the RMPs. The rights of way in question in this litigation originate from $\S 2477$ of the Revised Statutes of the United States of $1875^{79}$ (R.S. 2477), an 1866 statute that granted "[t]he right of way for the construction of highways over public lands, not reserved for public use. ${ }^{\prime 80}$ Interpretation and application of this statute has involved protracted litigation, ${ }^{81}$ and the United States Court of Appeals for the Tenth Circuit holds that establishment of a right of way under R.S. 2477 requires a showing of continuous public use for a period of ten years preceding the statute's 1976 repeal. $^{82}$

In pursuing its claims, the State defers heavily to counties for the determination of which routes were in existence and satisfied applicable requirements as of R.S. 2477's repeal. Utah counties and the State have, generally speaking, been reluctant to give up R.S. 2477 right of way claims. ${ }^{83}$ In light of Utah's claims of ownership to rights of way in these routes, we suspect that BLM may be reluctant to close routes to travel until ownership interests in those routes are resolved. Thus, as explained in the ROD for the Monticello RMP:

78 See Utah's Public Lands Policy Coordinating Office, Current Litigation, http://public lands.utah.gov/rs-2477-roads/current-litigation/ (last visited Nov. 19, 2016) (including links the state's twenty-two pending complaints). Geoff Liesik, Utah Counties File Lawsuits Against BLM Over RS2477 Roads, DESERET NEwS, May 4, 2012, http://www.deseretnews.com/article/ 865555277/Utah-counties-file-lawsuits-against-BLM-over-RS2477-roads.html?pg=all (last visited Nov. 19, 2016).

79 Mining Act of 1866, ch. 262, § 8, 14 Stat. 251, 253, repealed by Federal Lands Policy and Management Act of 1976, Pub. L. No. 94-579, § 706(a), 90 Stat. 2744, 2793. R.S. 2477, originally section 8 of the Mining Act of 1866 was codified in 1873 as $\S 2477$ of the Revised Statutes, and later recodified in 1938 as 43 U.S.C. $§ 932$ (1938).

80 Id.

81 See, e.g., Utah's Pub. Lands Policy Coordinating Office, R.S. 2477 Law Library, http://publiclands.utah.gov/rs-2477-roads/plpco-law-library/ (last visited Nov. 19, 2016) (containing links to eighteen court opinions relating to R.S. 2477).

82 S. Utah Wilderness All. v. U.S. Bureau of Land Mgmt., 425 F.3d 735, 771 (10th Cir. 2005).

83 See, e.g., Utah's Pub. Lands Policy Coordinating Office, R.S. 2477 FAQ, http://publiclands. utah.gov/rs-2477-roads/r-s-2477-faq/ (last visited Nov. 19, 2016) ("In 2012, the Utah Attorney General's Office filed 22 lawsuits in the federal court claiming title to R.S. 2477 rights-of-way.”). 
The Approved RMP does not adjudicate, analyze, or otherwise determine the validity of claimed rights-of-way. ... The BLM is committed to working with the State to employ potential options to recognize existing rights-of-way in accordance with [existing federal policy]. ... BLM will work with the State and counties to set priorities for specific roads. ${ }^{84}$

With this in mind, we note that closing routes to which the state claims an interest could have exacerbated tensions and compromised efforts to resolve disputes without litigation. Furthermore, closing roads that are subject to disputed claims of title would create a ripe claim or controversy that would overcome one of the procedural hurdles plaguing state litigation efforts. ${ }^{85}$

Outside of Utah, there appears to be a trend towards reducing route designations during the RMP revision process. This reduction would reduce both maintenance costs for BLM, and resource damage resulting from a proliferation of poorly maintained roads. The reduction, however, may also reduce access to some BLM-managed lands and resources.

\section{Terrain Open to Cross-County Motorized Travel}

Off-road vehicle (ORV) use is "one of the fastest growing categories of outdoor activity in the country." ${ }^{\text {"86 }}$ ORV use can have diverse and "profound" effects on soil, plant communities, wildlife, water quality, and nonmotorized recreationists. ${ }^{87}$ Two executive orders guide ORV management. ${ }^{88}$ Taken together, these executive orders direct BLM to, among other things, monitor the effects of ORV use and to "designate specific areas and trails on public lands as open or closed with respect to [ORV] use." ${ }^{" 89}$ BLM, through the RMP process, designates areas as "open," "closed," or "limited" to ORV use "based on the protection of the resources of the public lands, the promotion of the safety of all the users of the public lands, and the minimization of conflicts among various uses of the public lands." "[A]ll types of vehicle use is

84 MONTICELlo ROD, supra note 72, at 17.

85 See Kane County v. United States., 772 F.3d 1205, 1212-14 (10th Cir. 2014) (holding that disclaimer of the county's claim of title to the road in question, absent further action to prohibit or limit use, was insufficient to constitute a disputed title under the Quiet Title Act, 28 U.S.C. $\S 2409 \mathrm{a}(2012))$.

86 H. Ken CORDEll et AL., OFF-Highway VeHicle RECREATION IN THE UNITED STATES AND ITS REgions AND States: A NATIONAL REPORT FROM THE NATIONAL SURVEY ON RECREATION AND THE ENVIRONMENT (NSRE) 9-10 (2008), available at http:/www.fs.fed.us/recreation/programs/ ohv/IrisRec1rpt.pdf.

87 Douglas S. OUREn ET AL., U. S. Geological Survey, EnVIRONMENTAL EFFECTS OF OFFHighway Vehicles ON BUREAU OF LAND MANAGEMENT LANDS: A Literature Synthesis, ANNOTATED BIBLIOGRAPHIES, EXTENSIVE BIBLIOGRAPHIES, AND INTERNET RESOURCES 60 (2007).

88 Use of Off-Road Vehicles on the Public Lands, Exec. Order No. 11,644, 3 C.F.R. at 368 (1972) (as amended by Off-Road Vehicles on Public Lands, Exec. Order No. 11,989, 3 C.F.R. at 120 (1977)).

89 U.S. Gov't AcCountability OfFice, GAO-09-509, Federal Lands: Enhanced PlanNING

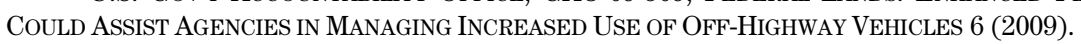

9043 C.F.R. $\S 8342.1$ (2015). 
permitted at all times" in open areas. ${ }^{91}$ Conversely, ORV use is prohibited in closed areas, absent special approval. ${ }^{92}$ Limited areas can include any type of restriction including timing of use restrictions, specific vehicles restrictions, number of vehicles restrictions, requirements that ORVs be restricted to designated roads and trails, or others. ${ }^{93}$ Because the limited ORV use classification encompasses a wide variety of restrictions ranging from very minor timing limitations to nearly complete prohibitions, we focused our analysis on the amount of area open to ORV use.

We found that the area open to ORV use declined dramatically during RMP revisions. Areas open to ORVs decreased, on average, by 410,493 acres, amounting to a $67 \%$ reduction. This reduction was statistically significant $(p<.01)$. The reduction in areas open to unrestricted ORV travel far outpaced the reduction in the number of designated roads and trails that are open to ORV use. This approach to impact reduction appears consistent with an effort on the part of BLM to reduce impacts to sensitive resources while minimizing access restrictions.

Notably, BLM reduced the area open to ORV travel in all six Utah RMPs by at least 99\%-a higher rate of reduction than that seen in any other state, and in all but one RMP from the other states. It may be that the State of Utah's aggressive stance with respect to routes across federal public lands led BLM to more aggressively regulate cross-country ORV use.

\section{Oil and Gas Development}

We observed a $26 \%$ acreage reduction in the amount of BLM-managed land open to O\&G development under "standard lease terms and conditions" between the No Action Alternative and the approved plan. Standard lease terms and conditions are the least restrictive leasing option available. ${ }^{94}$ This reduction was statistically significant $(p<.05)$. There was no statistically significant change in the amount of land open to O\&G development under "moderate constraints," an intermediate level of constraint involving timing limits or surface use stipulations, but the $71 \%$ increase in the amount of land subject to "major constraints" (no surface occupancy) and $42 \%$ increase in the area closed to leasing were both significant $(p<.05$ and $p<.01$, respectively). ${ }^{95}$ Overall, these changes represent a clear shift towards resource protection.

While observing a clear trend towards more protective surface use stipulations, we observed very little change in the number of oil and natural gas wells anticipated between the No Action Alternative and the final

91 Id. $\S 8340.0-5(\mathrm{f})$

92 Id. $\$ 8340.0-5(\mathrm{~h})$.

93 Id. $\S 8340.0-5(\mathrm{~g})$.

94 See id. §3101.1-2 (2014) (requiring the use of a standard lease form, onto which additional stipulations and restrictions may be added); see also LAND USE PLANNING HANDBOOK, supra note 53, app. C., at 23-24 (explaining surface use stipulations).

95 LAND USE PlanNing HANDBOOK, supra note 53, app. C., at 23 (defining moderate and major constraints). 
decision. In fact, while surface protections increased, total well development anticipated also increased by $2 \%$. This increase in wells was not statistically significant. The increase in well counts at first appears to conflict with the general trend towards more restrictive surface use stipulations. We hypothesize, however, that the increase in well development in the face of more stringent surface use stipulations can be attributed to two factors: the existence of valid existing mineral rights, and the proliferation of clustered development and directional drilling.

In estimating the number of wells that would be drilled under each alternative, BLM prepares a "reasonably foreseeable development scenario" (RFDS) ${ }^{96}$ The RFDS considers two classes of leases: those leases already in existence, and those leases anticipated to be issued under the new RMP. ${ }^{97}$ Existing leases include surface use stipulations that were in place at the time the lease was issued, and these stipulations, which are contractually agreed upon terms, do not change with RMP revisions. ${ }^{98}$ Since BLM has already conducted extensive leasing throughout the Intermountain West, most of the areas with high development potential have already been leased and will be developed under the stipulations contained in existing leases. ${ }^{99}$ It follows, therefore, that development of existing leases may explain the increase in anticipated well numbers. Development of existing leases could reflect initial development of previously leased but undeveloped fields, infill development of existing oil and gas fields, or a combination of both.

The RMPs also emphasized a shift towards clustered development and directional drilling. ${ }^{100}$ "Clustered development ... not only reduce[s] surface

96 See, e.g., U.S. Bureau of Land MGmt, Reasonably Foreseeable Development Scenario For Oil and Gas In The Moab Master Leasing Plan area, Canyon Country District (2012) ("A Reasonably Foreseeable Development (RFD) Scenario for oil and gas is a long-term projection of oil and gas activity.... Future oil and gas drilling for the next 15 years is projected to average 8.5 wells per year for a total of 128 wells.").

97 Id. at 3; see also U.S. Bureau of Land Mgmt., H-1624-1 Planning For Fluid Mineral RESOURCES, at IV-1 (1990) [hereinafter U.S. BUREAU OF LAND MGMT., H-1624-1] (stating the five categories of leases that the RMP must identify); Press Release, U.S. Bureau of Land Mgmt., BLM Utah Posts List of Proposed Parcels for Geothermal Lease Sale and Quarterly Oil and Gas Lease Sale (Nov. 4, 2008), http://www.blm.gov/ut/st/en/info/newsroom/2008/november/blm_ utah_posts_list.html.

html (last visited Nov. 19, 2016) (explaining the leasing process).

98 U.S. BuREAU OF LAND MGMT., H-1624-1, supra note 97, at I-2, IV-2 (stating circumstances when RMP revisions are permitted and describing example when surface use stipulation may be revised).

99 See U.S. Bureau of Land Mgmt., OIL AND Gas Statistics by Year For Fiscal Years 19882015 tbl.1 (2015), available at https://www.blm.gov/wo/st/en/prog/energy/oil_and_gas/ statistics.html (select "Table 1. Summary of Onshore Oil and Gas Statistics") (showing 32,193,369 acres currently under lease).

100 See, e.g., 2 PRICE FIELD OFFICE DRAFT RMP, supra note 70, at 4-280 ("Directional drilling could facilitate resource extraction on leases with constraints [No Surface Occupancy] or surface use restrictions ... [it] can also be used to mitigate impacts by allowing multiple wells on a single well pad."); Kanab Field Office, U.S. Bureau of Land MgMt., 1 Proposed Resource Management Plan and Final Environmental Impact Statement 4-108 (2008) [hereinafter KANAB RMP] ("Areas open to leasing subject to major constraints (NSO) (83,400 acres) could require directional drilling ... [this] could result in the relocation of facilities ...."). 
impacts due to fewer pads, [but] reduce[s] the need for new roads and vehicular travel associated with operation and maintenance of the wells." ${ }^{101}$ The focus on directional drilling allows access to mineral resources within areas that may otherwise have been closed to development; for example, the Roan Plateau RMP increased No Surface Occupancy (NSO) protected acreage from 13,912 to 17,736 acres. ${ }^{102}$ However, this increase appears to have affected the location of wells rather than the number of wells, as directional drilling allows access to "more than 90 percent [of mineral resources] in areas with [a NSO] restriction." ${ }^{103}$ Increased reliance on clustered development and directional drilling, therefore, allowed BLM to implement more of protective surface restrictions without a substantial impact on well numbers.

Surface use stipulations, it should be noted, apply beyond the O\&G context. As the Monticello and Moab RMPs both note, restrictions on mineral development "apply not only to oil and gas leasing, but also to all other surface disturbing activities associated with land-use authorizations, permits, and leases." ${ }^{104}$ In light of this broad applicability, the shift towards more stringent surface use stipulations provides a strong indicator of changed management priorities towards greater resource protection.

\section{Air Quality}

The RMP EIS process did not result in statistically significant changes in four measured air quality parameters. $\mathrm{PM}_{2.5}$ and $\mathrm{SO}_{2}$ emissions stayed roughly at No Action levels. $\mathrm{PM}_{10}$ emissions increased by roughly $5 \%$, however this result was not statistically significant. There was a slight (2\%) reduction in $\mathrm{NO}_{\mathrm{x}}$ emissions that is trending towards statistical significance $(p<0.1)$. In contrast, O\&G EISs resulted in $\mathrm{PM}_{10}, \mathrm{PM}_{2.5}$, and $\mathrm{NO}_{\mathrm{x}}$ emissions reductions of $23 \%$ or more. ${ }^{105}$ This discrepancy suggests that the most significant reductions in air emissions are the result of modifications to

101 Glenwood Springs Field office, U.S. Bureau of Land Mgmt., 1 Roan Plateau Proposed Resource Management Plan amendment and Final EnVironmental impact STATEMENT 2-7 (2006) [hereinafter ROAN RMP].

102 Compare id. at 4-120 tbl.4-30 (indicating that 13,912 acres were covered by NSO protections under the No Action Alternative), with GLEnwood SpRings Field OFFICE, U.S. Bureau of Land Mgmt., Record of Decision for the APProval of Portions of the RoAN Plateau Resource Management Plan Amendment and EnVironmental Impact Statement 12 (2007) (noting that under the adopted plan, 17,736 acres are covered by NSO protections). NSO generally "[p]rohibits long-term use or occupancy of the land surface for fluid mineral exploration or development to protect identified resource values." ROAN RMP, supra note 101, at 2-3. However, "an NSO does not preclude the extraction of underlying fluid minerals if they can be accessed from outside the area by directional drilling." Id.

103 ROAN RMP, supra note 101, at 2-7.

104 Monticello ROD, supra note 72, at 27; MOAB ROD, supra note 60, at 25 (containing similar language).

105 Ruple \& Capone, supra note 11, at 44 tbl.2. 
specific development proposals rather than programmatic decisions regarding the mix of uses occurring on BLM-managed public lands. ${ }^{106}$

\section{Impacts on Economic Metrics}

The RMP revision process, on average, appears to result in slightly positive economic impacts, as reflected in a $2 \%$ increase in the anticipated number of wells drilled and an $8 \%$ increase in anticipated O\&G related job creation. While these increases were not statistically significant, it is notable that statistically significant increases in the amount of BLM-managed lands subject to more protective surface use stipulations do not appear to come at the expense of development or jobs.

\section{Impact Reduction and Causation}

\section{Subsequent Impact Reduction}

RMPs contain broad-scale decisions, such as which areas will be open or closed to mineral development, and RMPs cover a planning area that can be several million acres in size. ${ }^{107}$ In this sense, RMPs are analogous to zoning, in that they determine what kinds of uses are acceptable without authorizing specific actions. The conceptual nature of RMPs is due in part to their long planning horizon; accordingly, RMPs may not be able to anticipate how foreseeable development will unfold. ${ }^{108}$ Similarly, because RMPs anticipate broad classes of development rather than discrete development proposals, RMP EISs generally lack the site-specific detail needed to address all future developments. ${ }^{109}$

The resulting multi-tiered planning and approval processes mean that NEPA can reduce impacts to the environment at multiple phases: first, by zoning development away from sensitive areas and applying general management requirements; and second, by creating an opportunity to refine more definite proposals in light of site-specific concerns. Accordingly,

106 See, e.g., Friends of Yosemite Valley v. Norton, 348 F.3d 789, 800 (9th Cir. 2003) (“An EIS for a programmatic plan ... must provide 'sufficient detail to foster informed decision-making,' but 'site-specific impacts need not be fully evaluated until a critical decision has been made to act on site development." (quoting N. Alaska Envtl. Ctr. v. Lujan, 961 F.2d 886, 890-91 (9th Cir. 1992)).

107 See, e.g., Vale Field Office, U.S. Bureau of Land Mgmt., Southeastern Oregon Resource MANAgEment Plan AND RECORd of DECision 2 (2002) ("The planning area considered in this document is 4.6 million acres.").

108 Vale Field Office, U.S. Bureau of Land Mgmt., 1 Proposed Southeastern Oregon Resource Management Plan and Final Environmental Impact Statement, at xii (2001) ("However, this planning document only identifies management for the 20-year life of the plan. The long-term vision may not be completely achieved under any alternative during the life of this plan.").

109 See, e.g., id. at 18 (2001) ("BLM has three primary levels of land use planning decisions; the RMP level, the activity level, and the site-specific level. This RMP focuses mostly on broad resource objectives and direction."). 
neither the environmental reductions discussed here nor in our earlier work on O\&G EISs, when considered in isolation, fully capture the impact reducing power of NEPA.

While we recognize a relationship between these tiered NEPA reviews, impact reductions at these levels cannot simply be added because impacts are generally measured using different indicators. Efforts to create a longitudinal assessment that can capture the total impact reduction therefore represents an important area for future research.

The longitudinal relationship between RMPs and subsequent O\&G development projects is particularly important because section 390 of the Energy Policy Act of $2005^{110}$ categorically excludes from NEPA analysis:

Drilling an oil or gas well within a developed field for which an approved land use plan or any environmental document prepared pursuant to NEPA analyzed such drilling as a reasonably foreseeable activity, so long as such plan or document was approved within 5 years [of] the date [drilling commences]. ${ }^{111}$

Accordingly, planning level NEPA can be used to authorize at least some infill development, even when that analysis lacks site-specific detail. ${ }^{12}$

\section{Reductions Driven by Other Environmental Laws}

As noted in our previous work on O\&G EISs, not all reductions occurring during the RMP revision process can be attributed to EIS preparation. ${ }^{113}$ Indeed, environmental statutes such as the Clean Air Act ${ }^{114}$ and Clean Water Act may be equally if not more effective at reducing environmental impacts.

Based on our results, the Clean Air Act does not appear to be driving substantial impact reduction during the RMP revision process. This is likely because the Clean Air Act is more influential at the site-specific planning level when BLM can require modifications to specific development

110 Pub. L. No. 109-58, § 390, 119 Stat. 594, 747-48 (codified at 42 U.S.C. § 15942 (2012)).

111 NEPA, 42 U.S.C. § 15942(b)(3).

112 The relationship between planning level NEPA and authorization of some infill development is explored further in Mark Capone \& John Ruple, NEPA and the Energy Policy Act of 2005 Statutory Categorical Exclusions: What are the Environmental Costs of Expedited Oil and Gas Development?, 18 VT. J. ENVTL. L. (forthcoming 2017) ("RMPs encompassing the proposed well satisfy the NEPA requirement, so long as the RMP 'contains a reasonably foreseeable development scenario broad enough to encompass this action.' This is problematic, as RMPs do not approve any site-specific decisions, but merely determines what areas are appropriate for specific uses." (quoting Memorandum from Kathleen Clarke, Dir., U.S. Bureau of Land Mgmt., on National Environmental Policy Act (NEPA) Compliance for Oil, Gas, and Geothermal Development (Sept. 30, 2005), available at http://www.blm.gov/wo/st/en/info/ regulations/Instruction_Memos_and_Bulletins/national_instruction/2005/IM_2005_247.html)).

113 Ruple \& Capone, supra note 11, at 48 ("O\&G development [authorization] necessitates a series of federal decisions preceding the O\&G EIS, each of which may trigger NEPA and provide an opportunity for impact reduction.").

11442 U.S.C. $\$ \S 7401-7671 q(2012)$. 
proposals. ${ }^{115}$ BLM also lacks jurisdiction to enforce the Clean Air Act and instead must rely on FLPMA's mandate to "protect the quality of scientific, scenic, historical, ecological, environmental, air and atmospheric, water resources, and archaeological values" to drive air quality protection. ${ }^{116}$ While BLM has limited authority to act in this area, they are taking affirmative steps by requiring operators within Utah to utilize certain best management practices and site-specific mitigation measures to "reduce emissions and enhance air quality." ${ }^{17}$

While the Clean Air Act appears to have only limited direct effect on RMP revisions, we suspect that the Endangered Species Act may play a significant role in shaping RMP revisions. Where listed species or their critical habitat are identified, BLM may reasonably conclude that the most effective means of avoiding adverse impacts to listed species or their habitat is to limit disturbance within these areas. In the current study, BLM took several protective actions in response to sensitive or listed species concerns. The actions included closing areas to ORV travel, closing roads, limiting surface disturbing development, and reducing grazing. ${ }^{118}$ To the extent that management stipulations set forth in revised RMPs avoid conflicts, they may steer development towards more appropriate areas, and in so doing, minimize conflicts and expedite subsequent tiered NEPA documents completed at the implementation phase.

\section{Intervening Technological Factors}

As noted in our earlier assessment of impact reduction occurring during preparation of EISs for O\&G projects, the maturation and convergence of directional drilling and hydraulic fracturing technologies has allowed O\&G operators to drill multiple wells from a single well pad. ${ }^{119}$ With fewer pads,

115 Ruple \& Capone, supra note 11, at 48-49.

116 FLPMA, 43 U.S.C. $\S 1701(a)(8)$ (2012).

117 E.g., MOAB ROD, supra note 60, at 53. Similar language is contained in the RODs for all six RMPs within Utah that were revised in 2008.

118 All of the RMP EISs referred to sensitive, threatened, or endangered species protection, to differing extents, as justification for land use decisions. See, e.g., LITTLE SNAKE FIELD OFFICE, U.S. Bureau of Land Mgmt., 2 Little Snake Proposed Resource Management Plan and Final Environmental ImPaCt STATEMENT 4-84 (2010) [hereinafter LiTTLE SNAKE RMP] ("Closing to oil and gas leasing 13 percent of the RMPPA mineral estate (242,560 acres), and applying NSO stipulations on 201,890 acres (10\% of the RMPPA) and CSU on 1,236,810 acres (64\% of the RMPPA) would directly protect and minimize disturbance to special status species habitat, threatened and endangered species, and vital habitat components."); DILLON FIELD OFFICE, U.S. Bureau of Land Mgmt., 1 Proposed Dillon Resource Management Plan and Final ENVIRONMENTAL ImPACT STATEMENT 320 (2005) (“[The preferred] alternative designates about 64 percent of all existing roads as open. Reduced road density in this alternative would enhance all Special Status Species wildlife uses of suitable habitat across the planning area. Density in the grizzly bear use area is about one-half mile open road per square mile which exceeds conservation criteria."); KANAB RMP, supra note 100, at 4-31 ("Managing OHV use throughout the majority of the decision area (528,000 acres, 95 percent) as limited to 1,403 miles of designated routes would minimize surface disturbances to [the Coral Pink Sand Dunes tiger beetle, a candidate for ESA listing at the time].").

119 Ruple \& Capone, supra note 11, at 49-50. 
operators require fewer roads and pipelines to connect their facilities. These impact reductions translate directly into reduced surface disturbance, which translates into reduced re-entrained road dust, habitat fragmentation, and other environmental impacts. This means that technological advances may drive some amount of impact reduction, though NEPA's public input requirements and evaluation of feasible alternatives may drive earlier adoption of these technologies.

That being said, we do not believe that the impact reductions observed during the RMP revision (planning) phase are as heavily influenced by changes in technology. BLM's initial decision, to allow development and under what conditions, is generally technology neutral. BLM, through the RMP revision process, does not propose O\&G or similar developments, but rather, determines which lands are available to be leased and under what conditions. These decisions are based on environmental considerations such as steepness of slope or the existence of endangered species. ${ }^{120}$ It is very likely, however, that technological advances explain why the number of jobs created or the pace of O\&G development remained stable in the face of increasing surface use stipulation. For example, technological advances, such as directional drilling, may allow access to mineral resources even though BLM has determined a particular area sensitive enough to warrant NSO stipulation.

\section{CONCLUSIONS}

The combined NEPA/FLPMA review associated with an RMP revision takes longer than completion of an EIS for an O\&G field development. This is not surprising given the broader geographic scope of RMP revisions and the wide-ranging issues involved in balancing competing uses. Efforts to expedite the process are understandable given the time involved in RMP revisions. Draft RMP EISs that are completed on an accelerated timeline, however, come with a heightened risk that supplementation will be needed. The breadth and complexity involved in RMP revisions demands careful analysis, and the likelihood that rapidly prepared DEISs for RMP revisions will require supplementation should stand as a caution against rushed efforts. While rushing DEIS completion can initially save time, they are far more likely to require supplementation or revision, and the added time involved in revising an inadequate DEIS far outweighs the timesaving associated with fast-tracking DEIS preparation.

EISs for RMP revisions are necessarily conceptual in nature, as these plans cover millions of acres and make broad land use allocation decisions. The nature of these decisions and differences between BLM field offices make it difficult to identify environmental impact indicators that are common to all RMP revisions. Based on our review of sixteen EISs

120 See, e.g., LITTLE SNAKE RMP, supra note 118, at 4-84 (specifically considering how an action would "protect and minimize disturbance to special status species habitat, threatened and endangered species, and vital habitat components"). 
completed as part of the RMP revision process, we found that BLM is significantly reducing the amount of terrain open to unrestricted crosscountry ORV travel and applying more protective surface use stipulations. Furthermore, reductions in the amount of roads open to motorized travel and number of livestock grazing on public lands are trending towards statistical significance. We lack the data, however, to quantify the environmental benefit of these actions and generalize across multiple projects. Despite the lack of empirical data, placing greater controls on development near sensitive resources will likely avoid environmental impacts and reduce the need to modify future development proposals.

RMP revisions increased application of more protective surface use stipulations by statistically significant amounts without causing a statistically significant change in either the number of jobs created or the number of O\&G wells drilled. In fact, both the number of jobs created and wells drilled increased slightly despite strengthened environmental protections. These findings are consistent with our earlier work on EISs for O\&G field developments, where we found that statistically significant reductions in environmental impact can generally be achieved without a corresponding reduction in commodity production or economic benefit. ${ }^{121}$

As with our work on EISs for O\&G field developments, our analysis is exploratory in nature, and we recognize that our conclusions are constrained by a small sample size. We also recognize that causal factors can be hard to isolate, and we hope that this effort will be seen as a helpful first step in assessing whether NEPA lives up to its promise. While our results are but a first step in empirically evaluating NEPA efficacy, it does appear that NEPA can produce significant reductions in environmental impacts without incurring a commensurate economic cost.

It may also be noteworthy that while it appears that Utah has had some success in convincing BLM to reduce ACEC designations and route closures, Utah's success on these fronts have been offset by the most significant percentage increases in the amount of acreage subject to NSO stipulations (91.8\%), and the most significant percentage reductions in lands open to cross-country ORV use (99.6\%). While these restrictions presumably reflect the unique resources at issue in each planning area, it is at least plausible that the unintended consequence of Utah's bellicose tone towards federal management ${ }^{122}$ has been federal retrenchment. Indeed, as a BLM spokeswoman recently said with respect to confrontations over public land management and Utah's antagonistic tone towards the federal government: "It is frustrating as we work to identify the best possible path forward for everyone when some of the entities we are trying to work with consistently

121 Ruple \& Capone, supra note 11 , at 46-47.

122 See, e.g., UTAH CODE ANN. §§ 63L-6-101 to -104 (West 2015) (demanding that the federal government extinguish title to 31.2 million acres of the public land, and transfer title to those lands to the state-these demands are founded in part on criticisms of federal land management). 
[Vol. 46:953

feel the need to poke us in the eye and then complain we are not working with them." ${ }^{123}$

123 Amy Joi O’Donoghue, Battle Between Utah's Rural Counties and BLM Intensifies, DESERET NEwS, June 28, 2014, http://www.deseretnews.com/article/865605994/Battle-betweenUtahs-rural-counties-and-BLM-intensifies.html?pg=all (last visited Nov. 19, 2016). 